\title{
Soil management and application of agricultural gypsum in a Planosol for soybean cultivation
}

\author{
Enio Marchesan ${ }^{1}$ Felipe Tonetto ${ }^{1}$ Gustavo Mack Teló ${ }^{2}$ Lucas Lopes Coelho ${ }^{1^{*}}$ \\ Bruno Behenck Aramburu ${ }^{1}$ Vinicius Severo Trivisiol ${ }^{1}$
}

${ }^{1}$ Departamento de Fitotecnia, Centro de Ciências Rurais (CCR), Universidade Federal de Santa Maria (UFSM), 97105-900, Santa Maria, RS, Brasil. E-mail: lucas_1_c@hotmail.com. *Corresponding author.

${ }^{2}$ Weed Science - AgCenter, Louisiana State University (LSU), 4115 Gourrier Av. Baton Rouge LA, 70803.

\begin{abstract}
This study investigated the effects of soil management systems, tillage, and application of gypsum agricultural to soil, on soybean development in lowland areas. The experiment was carried out on an Alfisol in a randomized complete block design in a factorial arrangement. The two soil tillage practices were without deep tillage and with deep tillage. Gypsum treatments were no gypsum application, $500 \mathrm{~kg}$ of gypsum ha-1, $1000 \mathrm{~kg}$ of gypsum ha-1, and $1500 \mathrm{~kg}$ of gypsum ha ${ }^{-1}$. Deep tillage resulted in less soil resistance to root penetration during ryegrass cultivation during the soybean offseason, 11 months after applying the management treatments, resulting in higher dry mass of ryegrass in the offseason and higher soybean yield in the following year.

Key words: Glycine max L., deep tillage, nodulation, grain yield.
\end{abstract}

Manejo do solo e aplicação de gesso agrícola em Planossolo para o cultivo de soja

RESUMO: O trabalho visou identificar o efeito de dois sistemas de manejo do solo, com e sem escarificação, associado à aplicação de gesso agrícola no desenvolvimento de plantas de soja em áreas de terras baixas. O trabalho foi realizado a campo, em Planossolo Háplico Eutrófico arênico, em esquema bifatorial (2x4) no delineamento experimental de blocos ao acaso composto por dois sistemas de manejo do solo: sistema sem escarificação do solo e sistema com escarificação do solo. Os tratamentos com gesso agrícola foram: testemunha sem aplicação de gesso agrícola, $500 \mathrm{~kg} \mathrm{ha}^{-1}$ de gesso agrícola, $1000 \mathrm{~kg} \mathrm{ha}^{-1}$ de gesso agrícola e $1500 \mathrm{~kg} \mathrm{ha}^{-1}$ de gesso agrícola. A escarificação do solo proporciona maior rendimento de grãos de soja em áreas de terras baixas com presença de camada compactada, independente do uso de gesso agrícola. Os efeitos da escarificação do solo resultam na menor resistência à penetração de raizes no final do cultivo do azevém na entressafra da soja, 11 meses após o manejo, resultando em maior massa seca do azevém em sucessão e produtividade da soja no ano seguinte.

Palavras-chave: Glycine max L., escarificação, nodulação, rendimento de grãos.

\section{INTRODUCTION}

Rotation and/or succession planting in lowland areas presents a challenge for irrigated rice cultivation. One of the major benefits of rotation or succession planting is the breaking up of cycles of pests, diseases, and hard-to-control weeds, especially weedy rice. In this context, soybean crops present a promising option. However, lowland areas present a limitation for cultivation of leguminous crops and their development.

In lowland areas, soil compaction and the low natural fertility levels are some of the soil characteristics restricting cultivation of dry or offseason crops. Soil compaction results in macroporosity reduction and greater density and resistance against penetration, which restrict root growth in addition to reducing water and nutrient availability for plants (CABRAL et al., 2012), compromising productivity due to higher stress susceptibility caused by the excess or deficit of water. Regarding chemical characteristics, soils in lowland areas are characterized by low natural fertility and reduced organic matter, phosphorus, and potassium contents. Furthermore, VEDELAGO et al. (2012) reported that approximately $40 \%$ of the soils planted with irrigated rice crops in Rio Grande do Sul, Brazil, showed aluminum saturation 
higher than $10 \%$, and $30 \%$ of the soils also showed exchangeable calcium content under $2 \mathrm{cmol} \mathrm{dm}^{-3}$ in the $0-0.2 \mathrm{~m}$ layer, which aggravates stress on plants such as soybean. Thus, the association of physical and chemical limitations in these soils may not only impair the absorption of water and nutrients by plants but also result in growth depth restriction for plant roots and impair the biological nitrogen fixation process (CALONEGO et al., 2011).

According to DALLA NORA et al. (2014), agricultural gypsum may be used as an environment enhancer for roots in sub-superficial layers with high aluminum content. In general, agricultural gypsum has greater solubility in water (150 times) compared with limestone, which enables better mobility and consequently better effects throughout the soil depth. Sulfate anions present in gypsum combines with $\mathrm{Ca}^{2+}$ and moves to the surface where they dissociate, release $\mathrm{Ca}^{2}$, and combine with $\mathrm{Al}^{3+}$ composing an insoluble ionic pair $\left(\mathrm{AlSO}_{4}^{+}\right)$(ZANDONA et al., 2015). This process removes aluminum from the CEC and permits roots to explore deeper soil layers throughout the soil profile.

However, chemical correction alone may not be sufficient to enable proper development of the soybean root system in these areas. Deep tillage may be an alternative for loosening the region where most roots and nodes are concentrated, enabling greater water storage in the soil (SARTORI et al., 2015). Therefore, this study aimed to evaluate the effects of two soil management systems, with and without deep tillage, and agricultural gypsum application in lowland areas on soybean crops.

\section{MATERIALS AND METHODS}

The experiment was conducted during the 2012/13 and 2013/14 cropping seasons on an Alfisol (EMBRAPA, 2013). Regional climate of the study area is classified as humid subtropical (Cfa) according to the Köppen's classification system, with approximately $1,616 \mathrm{~mm}$ average yearly rainfall.

The experimental design was $2 \times 4$ bifactorial model with randomized blocks in four replications. The first factor comprised two soil management systems, No Tillage System (NTS; without soil preparation), and Deep Tillage System (DTS; 0.30m depth), 30 days before soybean sowing using a five-shank chisel plow with shanks spaced $0.35 \mathrm{~m}$ apart.

The second factor consisted of agricultural gypsum doses as follows: T1: control, without gypsum application, T2: $500 \mathrm{~kg} \mathrm{ha}^{-1}, \mathrm{~T} 3: 1,000 \mathrm{~kg} \mathrm{ha}^{-1}$, and T4: $1,500 \mathrm{~kg} \mathrm{ha}^{-1}$ of gypsum. Agricultural gypsum was composed of $18 \%$ calcium and $26 \%$ sulfur, and was spread on the soybean sowing day in the first year. Each experimental unit consisted of $21 \mathrm{~m}^{2}$ of usable area. The BMX Potência soybean variety was selected for the experiment, and 30 seeds were sown per $\mathrm{m}^{2}$. Seeds were treated with Pyraclostrobin $\left(25 \mathrm{~g} \mathrm{~L}^{-1}\right)$, methyl thiophanate $\left(225 \mathrm{~g} \mathrm{~L}^{-1}\right)$, and fipronil $\left(250 \mathrm{~g} \mathrm{~L}^{-1}\right)$, at a rate of $200 \mathrm{~mL}$ per $100 \mathrm{seed} \mathrm{kg}^{-1}$, and inoculated with Bradyrhizobium japonicum strains.

In the 2012/13 cropping season, soybean sowing occurred on November 4, 2012, and basal dressing fertilization was performed using $40 \mathrm{~kg} \mathrm{~N}$ ha $^{-1}$, 90kg $\mathrm{P}_{2} \mathrm{O}_{5}$ ha $^{-1}$, and $135 \mathrm{~kg} \mathrm{~K}_{2} \mathrm{O} \mathrm{ha}{ }^{-1}$. Planting was performed using the MF 407 (Massey Ferguson) pantographic seed driller composed of six lines equipped with straw cutting discs and 22" fertilizer applicator discs with a $0.08 \mathrm{~m}$ working depth. Soil samples were collected from the $0-0.15$ and 0.16 $0.3 \mathrm{~m}$ depths 30 days before soybean sowing for physical and chemical analyses, presented in table 1 .

Initial plant population evaluation was performed 10 days after emergence by counting the plants from three meters of the sowed line. The aerial part dry mass and length, in addition to root dry mass and length, viable node dry mass, and number of viable nodes per plant, were evaluated during the R2 phenological stage (FEHR \& CAVINESS, 1977), using 10 plants collected from the second sowed line.

Aerial part length and dry mass evaluations were performed by cutting the plants at the ground level and measuring these parts using a graduated ruler. Thereafter, plants were stored in paper bags for aerial part dry mass estimation. Roots were collected through $0.4 \mathrm{~m}$ deep and $0.5 \mathrm{~m}$ wide trenches established perpendicularly to the sowed line. They were rinsed with running water, posteriorly measured using a graduated ruler, and stored for dry mass determination.

Node viability was determined following the methodology described by NETO et al. (2008). The same roots collected for length and dry mass determination were used, and the nodes were classified according to their diameters. Nodes larger than $2 \mathrm{~mm}$ were transversally sectioned for internal color evaluation. Pinkish colored nodes (active legoglobins) were considered viable, while dark or greenish colored nodes (inactive legoglobins) were considered non-viable. Node dry mass, and aerial part and root dry masses were determined using a forcedventilation oven at $65^{\circ} \mathrm{C}$ until constant mass, with posterior weighing using a precision scale.

Nitrogen $(\mathrm{N})$, phosphorus $(\mathrm{P})$, potassium $(\mathrm{K})$, calcium $(\mathrm{Ca})$, magnesium $(\mathrm{Mg})$, and sulfur $(\mathrm{S})$ 
Table 1 - Chemical analysis of the $0-15$ and $16-30 \mathrm{~cm}$ soil layers performed 30 days before sowing the soybean crop harvested in $2012 / 13$.

\begin{tabular}{|c|c|c|c|c|c|}
\hline $\mathrm{pH}\left(\mathrm{H}_{2} \mathrm{O}\right)(1: 1)$ & $\mathrm{K}$ & $\mathrm{Ca}$ & $\mathrm{Mg}$ & Effective CEC & pH 7 CEC \\
\hline \multicolumn{6}{|c|}{ - } \\
\hline 4.9 & 72.0 & 3.6 & 2.9 & 6.9 & 12.2 \\
\hline $\mathrm{P}$ & $\mathrm{S}$ & $\mathrm{Al}$ & $\mathrm{m}(\%)^{1}$ & $\mathrm{~V}(\%)^{2}$ & OM \\
\hline \multicolumn{2}{|c|}{---------------------'mg dm³ --------------------- } & $\mathrm{mmol}_{\mathrm{c}} \mathrm{dm}^{-3}$ & -----------------. & 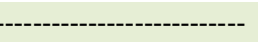 & $\mathrm{g} \mathrm{dm}^{-3}$ \\
\hline 7.6 & 12.0 & 0.2 & 2.9 & 54.7 & 2.0 \\
\hline \multicolumn{6}{|c|}{ 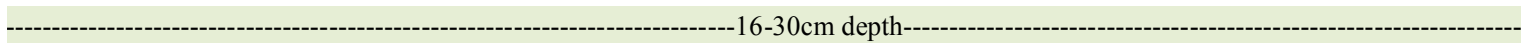 } \\
\hline $\mathrm{pH}\left(\mathrm{H}_{2} \mathrm{O}\right)(1: 1)$ & $\mathrm{K}$ & $\mathrm{Ca}$ & $\mathrm{Mg}$ & Effective CEC & pH 7 CEC \\
\hline \multicolumn{6}{|c|}{ 1 } \\
\hline 4.3 & 24.0 & 1.7 & 1.3 & 5.6 & 14.0 \\
\hline $\mathrm{P}$ & S & $\mathrm{Al}$ & $\mathrm{m}(\%)$ & $\mathrm{V}(\%)$ & $\mathrm{OM}$ \\
\hline \multicolumn{2}{|c|}{ 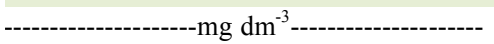 } & $\mathrm{mmol}_{\mathrm{c}} \mathrm{dm}^{-3}$ & ------------------ & -------------------------- & $\mathrm{g} \mathrm{dm}^{-3}$ \\
\hline 3.0 & 13.0 & 2.5 & 44.6 & 54.7 & 1.3 \\
\hline
\end{tabular}

${ }^{1}$ aluminum saturation; ${ }^{2}$ base saturation.

contents in soybean leaves were determined using the third fully expanded leaves, from the apex to the bottom, of 20 plants per experimental unit during the R2 phenological stage. Thereafter, samples were transferred to the Forest Ecology Laboratory of the Universidade Federal de Santa Maria (UFSM) where analyses were performed. Soil mechanical resistance was determined during the $\mathrm{R} 2$ stage, using a Falker PLG 1020 digital penetrometer, with five measurements performed per experimental unit at the $0.40 \mathrm{~m}$ depth in the sowed line.

Grain productivity was determined through manual harvesting from a $7.5 \mathrm{~m}^{2}$ area. Numbers of pods and grains per plant were determined for 10 plants, sequentially collected from the second sowed line of each experimental unit.

The ryegrass seed was spread while the soybean crop was at the R7/R8 phenological stage (April 3, 2013) at a rate of $40 \mathrm{~kg}$ of seed ha 1. Fertilization was performed using two $40 \mathrm{~kg} \mathrm{~N}$ ha $^{-1}$ applications on the $40^{\text {th }}$ and $75^{\text {th }}$ days after sowing. Three $0.50 \mathrm{~m}^{2}$ subsamples were collected from each experimental unit for ryegrass dry mass determination: on June 10, August 13, and September 25,2013 , for the first, second, and third subsamples, respectively. The samples were dried using a forced ventilation oven at $65^{\circ} \mathrm{C}$. Soil mechanical penetration resistance was measured on August 27, 2013.

Ryegrass harvesting and soybean sowing were performed on November 26,2013, using the same experimental units of the 2012/13 cropping season, but without the implementation of soil management systems and agricultural gypsum application. Basal dressing fertilization included $40 \mathrm{~kg} \mathrm{~N} \mathrm{ha}^{-1}, 90 \mathrm{~kg} \mathrm{P}_{2} \mathrm{O}_{5}$ $\mathrm{ha}^{-1}$, and $135 \mathrm{~kg} \mathrm{~K}_{2} \mathrm{O} \mathrm{ha}{ }^{-1}$. The variables evaluated during the second year included number plants per square meter, number of pods per plant, number of grains per plant, and grain productivity, using the procedures described above.

The obtained data was analyzed using the mathematic model presupposition test. The variance was determined using the $\mathrm{F}$ test. Because the investigated parameters did not show interactive effects, evaluation for the main effects was performed separately for each factor and significant means were compared using the Tukey's test at $5 \%$ error probability.

\section{RESULTS AND DISCUSSION}

The plant population and productivity components, as well as the plant growth characteristics such as aerial part and root lengths and aerial part, root, and node dry masses, were not affected by application of gypsum. Consequently, the use of agricultural gypsum did not affect the soybean grain productivity (Table 2). Among the soil management systems, a $24 \%$ difference in grain productivity was observed: the deep tilled area presented $3,643 \mathrm{~kg}$ $\mathrm{ha}^{-1}$ productivity, while the non-tilled area presented $2,774 \mathrm{~kg} \mathrm{ha}^{-1}$ productivity. This difference may be partly associated with alterations in the root environment, which was verified through the root penetration mechanical resistance (Figure 1A), with the presence of a compacted layer at the $0.1 \mathrm{~m}$ depth 
Table 2 - Ryegrass dry mass and soybean plant population, number of pods per plantk, number of grains per plant, grain productivity, aerial part length (APL), root system length (RSL), aerial part dry mass (APDM), root system dry mass (RSDM), number of viable nodes (NVNP), and viable node dry mass (VNDM) under different soil management systems and agricultural gypsum (GP) doses.

\begin{tabular}{|c|c|c|c|c|c|c|}
\hline Gypsum doses $\left(\mathrm{kg} \mathrm{ha}^{-1}\right)$ & \multicolumn{2}{|l|}{ Plants $\left(m^{-2}\right)$} & Pods plant ${ }^{-1}$ & Grains plant ${ }^{-1}$ & \multicolumn{2}{|r|}{ GP $\left(\mathrm{kg} \mathrm{ha}^{-1}\right)$} \\
\hline 0 & \multicolumn{2}{|l|}{$25^{\mathrm{ns}}$} & $48^{\mathrm{ns}}$ & $116^{\mathrm{ns}}$ & \multicolumn{2}{|r|}{$3.210^{\mathrm{ns}}$} \\
\hline 500 & \multicolumn{2}{|l|}{24} & 49 & 121 & \multicolumn{2}{|r|}{3.204} \\
\hline 1000 & \multicolumn{2}{|l|}{25} & 49 & 120 & \multicolumn{2}{|r|}{3.206} \\
\hline 1500 & \multicolumn{2}{|l|}{24} & 49 & 116 & \multicolumn{2}{|r|}{3.226} \\
\hline NTS & \multicolumn{2}{|l|}{$25^{\mathrm{ns}}$} & $44 b^{*}$ & $108 b$ & \multicolumn{2}{|r|}{$2.774 \mathrm{~b}$} \\
\hline DTS & \multicolumn{2}{|l|}{25} & $53 \mathrm{a}$ & $128 \mathrm{a}$ & & $3.643 \mathrm{a}$ \\
\hline $\mathrm{CV} \%$ & 6.2 & & 6.7 & 7.4 & & 2.3 \\
\hline Gypsum doses $\left(\mathrm{kg} \mathrm{ha}^{-1}\right)$ & $\operatorname{APL}(\mathrm{cm})$ & $\operatorname{RSL}(\mathrm{cm})$ & $\operatorname{APDM}(g)$ & RSDM (g) & NVNP & $\operatorname{VNDM}(g)$ \\
\hline 0 & $80.9^{\text {ns }}$ & $18.5^{\mathrm{ns}}$ & $24.3^{\mathrm{ns}}$ & $4.2^{\mathrm{ns}}$ & $29^{\mathrm{ns}}$ & $1.6^{\mathrm{ns}}$ \\
\hline 500 & 80.3 & 18.4 & 23.9 & 4.3 & 31 & 1.6 \\
\hline 1000 & 81.6 & 18.8 & 24.8 & 4.2 & 30 & 1.6 \\
\hline 1500 & 77.5 & 19.3 & 23.2 & 4.4 & 30 & 1.6 \\
\hline 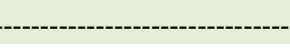 & 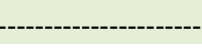 & ------S & il management---- & - & - & 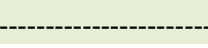 \\
\hline NTS & $73.1 \mathrm{~b}$ & $15.9 \mathrm{~b}$ & $17.1 \mathrm{~b}$ & $3.9 \mathrm{~b}$ & $27 b$ & $1.3 \mathrm{~b}$ \\
\hline DTS & $86.9 \mathrm{a}$ & $21.8 \mathrm{a}$ & $31.1 \mathrm{a}$ & $4.7 \mathrm{a}$ & $32 a$ & $1.9 \mathrm{a}$ \\
\hline $\mathrm{CV} \%$ & 5.1 & 8.5 & 5.5 & 10.1 & 5.6 & 2.8 \\
\hline - & ---------------- & ----------Off & eason (ryegrass)-- & ------------------------ & --------- & ----------------------. \\
\hline Gypsum doses $\left(\mathrm{kg} \mathrm{ha}^{-1}\right)$ & $1^{\text {st }}$ harvest $(\mathrm{l}$ & $\left.\mathrm{g} \mathrm{ha}^{-1}\right)$ & $2^{\text {nd }}$ har & $\left.\mathrm{kg} \mathrm{ha}^{-1}\right)$ & $3^{\text {rd }} \mathrm{hr}$ & rvest $\left(\mathrm{kg} \mathrm{ha}^{-1}\right)$ \\
\hline 0 & $1.031^{\mathrm{n}}$ & & & & & $2.625^{\mathrm{ns}}$ \\
\hline 500 & 1.124 & & & & & 2.732 \\
\hline 1000 & 1.050 & & & & & 2.721 \\
\hline 1500 & 1.109 & & & & & 2.621 \\
\hline  & --------------- & --------S & il management---- & (-) & & - \\
\hline NTS & $893 b$ & & & & & $2.293 b$ \\
\hline DTS & 1.259 & & & & & $3.056 \mathrm{a}$ \\
\hline $\mathrm{CV} \%$ & 10.2 & & & & & 9.5 \\
\hline  & ------------------- & ------Soybc & an 2013/14 harvest & 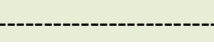 & ---- & ------------------- \\
\hline Gypsum doses $\left(\mathrm{kg} \mathrm{ha}^{-1}\right)$ & Plants $\left(m^{-2}\right)$ & & Pods plant $^{-1}$ & Grains plant $^{-1}$ & & $\mathrm{GP}\left(\mathrm{kg} \mathrm{ha}^{-1}\right)$ \\
\hline 0 & $25^{\mathrm{ns}}$ & & $58^{\mathrm{ns}}$ & $133^{\text {ns }}$ & & $3.486^{\text {ns }}$ \\
\hline 500 & 24 & & 56 & 131 & & 3.552 \\
\hline 1000 & 24 & & 57 & 131 & & 3.519 \\
\hline 1500 & 24 & & 57 & 136 & & 3.523 \\
\hline 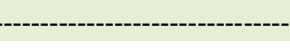 & ------ & ----------S & il management----. & 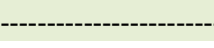 &  & ----- \\
\hline NTS & $25^{\mathrm{ns}}$ & & $54 b^{*}$ & $126 \mathrm{~b}$ & & $3.267 \mathrm{~b}$ \\
\hline DTS & 25 & & $60 \mathrm{a}$ & $139 a$ & & $3.764 a$ \\
\hline $\mathrm{CV} \%$ & 4.8 & & 11.4 & 6.2 & & 5.6 \\
\hline
\end{tabular}

"Means not followed by the same letter differ according to Tukey's test at 5\% probability, ${ }^{\text {ns }}$ not significant according to Tukey's test at $5 \%$ probability, NTS - no tillage system, DTS - deep tillage system.

Ciência Rural, v.47, n.11, 2017. 


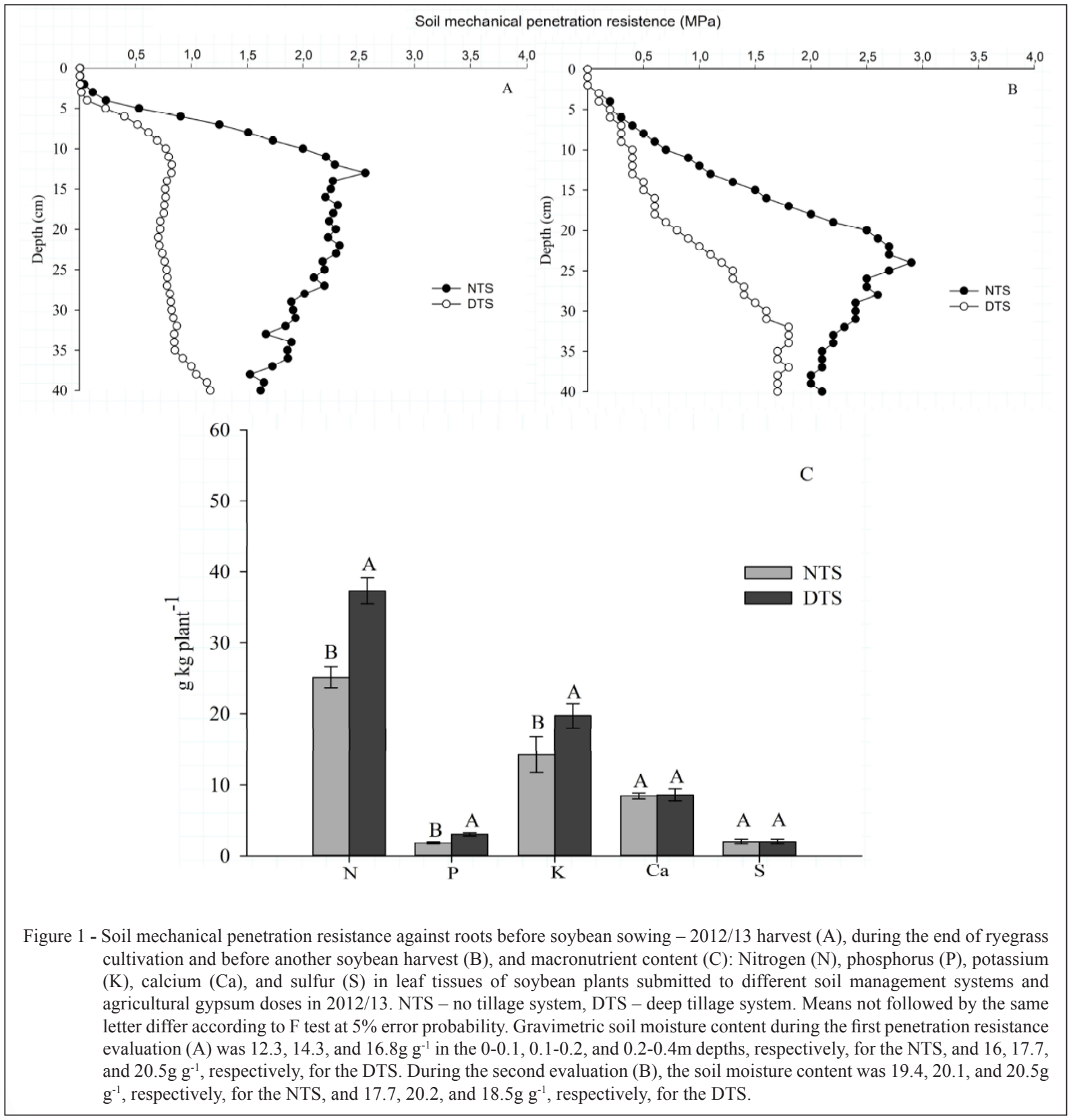

for the non-tilled system, which was significantly reduced by the deep tillage process. Penetration resistance is one of the soil physical attributes used as indicators of compaction, and penetration resistance values higher than $2 \mathrm{MPa}$ are considered limiting for the plant root system (SUZUKI et al., 2007). Deep tilled soil presented $\leq 2 \mathrm{MPa}$ penetration resistance up to the $0.40 \mathrm{~m}$ deep layer.

Soil compaction reduced the plant aerial part and root lengths (Table 2). In agreement with this result, GIACOMELI et al. (2016) reported that deep tillage contributes to increasing the soil porosity and consequently, reduces soil bulk density by breaking the compacted layer. This soil management procedure tends to positively affect plant development, because it enables roots to explore a larger area. Root development in compacted soils is limited, which impairs nutrient exploitation and water absorption by plants (VOLTAN et al., 2000). Soil compaction effects, reflected on the aerial 
part and root lengths, may also be reflected in the root and aerial part dry mass reductions. Use of agricultural gypsum did not affect the parameters investigated in this study, which may be related to the low aluminum saturation (Table 1) in the soil layer where the plants root system is concentrated (0-0.2m depth).

The deep tilled soil presented a large number of viable nodes and higher node dry mass per plant (Table 2). This may be associated with the effects of deep tillage, which tends to provide better aeration in the plant root region and improves drainage in the soil profile affecting nodulation, which is very sensitive to water excess (SARTORI et al., 2015). Plants with satisfactory root development show better usage of sucrose, which is produced by photosynthesis and transported to the nodes, turning into alpha-keto acid and participating in the nitrogenase metabolism (COKER \& SCHUBEL, 1981), which enables the maintenance of symbiosis in bacterial colonies and positively affects the symbiotic nitrogen fixation process and consequently grain productivity.

The nitrogen, phosphorus, and potassium macronutrient contents in plant tissues increased under the deep tillage system (Figure 1C) irrespective of the doses of agricultural gypsum. This behavior may be related to the greater development of the root system observed in the area under deep tillage, due to the lower mechanical penetration resistance. SILVA \& ROSOLEM (2001) associated the higher absorption of nitrogen, phosphorus, and potassium by soybean plants with less dense soils, a parameter which directly affects the soil penetration resistance. Calcium and sulfur contents were not affected by the management systems and agricultural gypsum applications, indicating that the contents of these nutrients were sufficient for the crop needs for high grain productivity (URANO et al., 2007).

Ryegrass planted following the soybean crop in the same area (Table 2) did not show the effects of agricultural gypsum application on dry mass production. However, deep tillage performed before soybean sowing provided higher dry mass production in two of the three evaluations, with a $23 \%$ increment at the last quantification time point. This may be related to the persistence of the effects of deep tillage of the soil, represented by the soil mechanical penetration resistance: lower penetration resistance values were observed up to $0.4 \mathrm{~m}$ depth, 11 months after implementation of deep tillage, compared with the no-tillage system. Furthermore, the use of ryegrass during the offseason may have contributed to the maintenance of this effect, because plants with an extensive root system promote the aggregation of soil particles over time (DEBIASI et al., 2010).

In the same area, the soybean grain productivity components in the 2013/14 season, after the ryegrass cultivation season, were not affected by gypsum application during that period. However, deep tillage of the soil performed during the previous year provided higher grain productivity compared with the non-tilled area. This result suggested that part of the soil alterations resulting from the tillage effect remained during the subsequent cultivation periods. A study conducted by DRESCHER et al. (2016) reported that alterations in the physical and water properties caused by tillage in Latosols persist in the subsequent periods, varying from six months for properties such as density, porosity, and macro porosity; and up to 24 months for parameters such as penetration resistance, water conductivity, and soil water infiltration rate.

\section{CONCLUSION}

Deep tillage resulted in higher grain productivity of soybean plants cultivated in lowland areas with a compacted layer present close to the surface, independent of agricultural gypsum application. For the achieved productivity levels of soybean in lowland areas, there was no performance response to the application of agricultural gypsum under sufficient calcium and sulfur availability in the soil. Benefits of deep tillage of the soil, such as low penetration resistance, are sustained during the second cultivation season, favoring offseason ryegrass and succession soybean crops.

\section{REFERENCES}

CABRAL, C.E.A. et al. Soil compaction and primary macro nutrients in Brachiaria brizantha cv. 'Piatã' and Panicum maximum cv. 'Mombaça' cover plants in compacted soil. Brazilian Agricultural and Environmental Engineering Magazine, v.16, p.362-367, 2012. Available from: <http://dx.doi.org/10.1590/ S1415-43662012000400005>. Accessed: Sept. 08, 2016. doi: $10.1590 /$ S1415-43662012000400005.

CALONEGO, J.C. et al. Coverage plants development in compacted soil. Bioscience Journal, v.27, p.289-296, 2011. Available from: <http:/www.seer.ufu.br/ biosciencejournal>. Accessed: Sept. 25, 2016. doi: 1981-3163.

COKER, G.T.; SCHUBEL, K.R. Carbon dioxide fixation in soybean roots and nodules. I. Characterization and comparison of $\mathrm{N}_{2}$ fixation and composition of xylem exudates during the early nodule development stage. Plant Physiology, v.67, p.691-696, 1981.

DEBIASI, H. et al. Soybean and corn productivity after winter coverage and mechanical soil loosening. Brazilian Agricultural 
Research, v.45, n.6, p.603-612, 2010. Available from: <http:// www.scielo.br/pdf/pab/v45n6/a10v45n6.pdf>. Accessed: May 31, 2017. doi: 0.1590/S0100-204X2010000600010.

DALLA NORA, D. et al. Chemical soil alterations and corn productivity with application of gypsum combined with limestone. Magistra, v.26, p.1-10, 2014.

DRESCHER, M.S. et al. Duration of physical and water properties alterations in Latosols due to mechanical deep tillage. Brazilian Agricultural Research, v.51, p.159-168, 2016. Available from: <http://dx.doi.org/10.1590/S0100-204X2016000200008>. Accessed: Nov. 15, 2016. doi: 10.1590/S0100-204X2016000200008.

EMPRESA BRASILEIRA DE PESQUISA AGROPECUÁRIA (EMBRAPA). Brazilian soil classification system. 3.ed. Brasília, Brazil: Embrapa, 2013. 353p.

FEHR, W.R.; CAVINESS, C.E. Stages of soybean development Ames: State University of Science and Technology, 1977. 11p. (Technical bulletin, 80).

GIACOMELI, R. et al. Soil deep tillage and chisels on planters for corn cultivation in Planosols. Brazilian Agricultural Research, v.51, p.261-270, 2016. Available from: < http://dx.doi.org/10.1590/ S0100-204X2016000300008>. Accessed: Nov. 15, 2016. doi: 10.1590/S0100-204X2016000300008.

NETO, S.A.V. et al. Inoculant application methods and its effects on soybean nodulation. Brazilian Soil Science Magazine, v.32, p.861-870, 2008. Available from: <http://dx.doi.org/10.1590/ S0100-06832008000200040>. Accessed: Aug. 10, 2016. doi: $10.1590 / \mathrm{S} 0100-06832008000200040$

VOLTAN, R.G. et al. Soybean root structure and plant development aspects in compacted soils. Brazilian Agricultural Research, v.35, p.929-938, 2000. Available from: < http://dx.doi.org/10.1590/ S0100-204X2000000500010>. Accessed: Oct. 15, 2016. doi: 10.1590/S0100-204X2000000500010.
SARTORI, GM.S. et al. Soybean grain productivity resulting from planting and surface irrigation systems in Planosols. Brazilian Agricultural Research, v.50, p.1139-1149, 2015. Available from: <http://dx.doi.org/10.1590/S0100204X2015001200003>. Accessed: Sept. 08, 2016. doi: 10.1590/ S0100-204X2015001200003.

SILVA, R.H.; ROSOLEM, C.A. Influence of the previous crop and soil compaction on soybean macronutrients absorption. Brazilian Agricultural Research, v.36, p.1269-1275, 2001. Available from: <http://dx.doi.org/10.1590/S0100204X2001001000009>. Accessed: Nov. 10, 2016. doi: 10.1590/ S0100-204X2001001000009.

SUZUKI, L.E.A.S. et al. Compaction level, physical properties, and crop productivity in Latosols and Argisols. Brazilian Agricultural Research, v.42, p.1159-1167, 2007. Available from: <http://dx.doi.org/10.1590/S0100204X2007000800013>. Accessed: Nov. 10, 2016. doi: 10.1590/ S0100-204X2007000800013.

URANO, E.O.M. et al. Determination of optimal nutrient contents in soybean using the mathematical CHANCE integrated diagnosis system and recommendation of the nutritional composition diagnosis methods. Brazilian Soil Science Magazine, v.31, p.63-72, 2007. Available from: <http://dx.doi.org/10.1590/S010006832007000100007>. Accessed: Nov. 12, 2016. doi: 10.1590/ S0100-06832007000100007.

VEDELAGO, A. et al. Soil fertility and usage aptitude for soybean cultivation in rice crop regions of Rio Grande do Sul, Brazil. Cachoeirinha: IRGA, 2012. 48p. (Research Division).

ZANDONA, R.R. et al. Gypsum and limestone increase productivity and reduce the effects of water deficit on corn and soybean. Tropical Agricultural Research, v.45, p.128137, 2015. Available from: <http://dx.doi.org/10.1590/198340632015v4530301>. Accessed: Sept. 20, 2016. doi: $10.1590 / 1983-40632015 \mathrm{v} 4530301$ 